\title{
PENERAPAN SCIENTIFIC APPROACH PADA PENGEMBANGAN PERANGKAT PEMBELAJARAN IPA UNTUK MELATIHKAN KETERAMPILAN BERPIKIR SISWA
}

\author{
Muh. Erwinto Imran \\ e-mail:muh.erwintoimran@yahoo.com
}

\begin{abstract}
Abstrak
Penelitian ini bertujuan untuk menghasilkan perangkat pembelajaran IPA berorientasi Scientific Approach yang valid, praktis, dan efektif untuk melatihkan keterampilan Berpikir Siswa. Pengembangan perangkat pembelajaran menggunakan model model 4-D dan diujicobakan di kelas V di Sekolah Dasar dengan One-Group Pretest-Posttest Design. Pengumpulan data menggunakan metode observasi, tes, dan angket. Teknik analisis data menggunakan analisis deskriptif kuantitatif, kualitatif dan uji T. Penelitian pengembangan ini bertujuan untuk mengetahui kualitas (validitas, kepraktisan, dan keefektifan) perangkat pembelajaran IPA Berorientasi Scientific Approach Untuk Melatihkan Keterampilan Berpikir. Penelitian ini dilaksanakan dalam dua tahap, yaitu pengembangan perangkat mengikuti model 4-D yang dikembangkan oleh Thiagarajan, Semmel dan Semmel, dilanjutkan implementasi perangkat pembelajaran di kelas. Hasil penelitian menunjukkan bahwa perangkat yang dikembangkan telah valid, praktis, dan efektif. Valid terlihat dari penilaian validator terhadap RPP; LKS; buku siswa; instrumen penilaian hasil belajar pengetahuan (keterampilan berpikir), keterampilan, dan sikap. Praktis terlihat dari persentase keterlaksanaan tahapan pembelajaran sebesar 100\%; skor keterlaksanaan pembelajaran di kelas V sebesar 3,60; aktifitas yang mendukung scientifiec approach lebih dominan dalam pembelajaran dan aktivitas tidak relevan mengalami penurunan setiap pertemuan; siswa memberikan respon positif terhadap perangkat dan proses pembelajaran berorientasi scientific approach yang telah dikembangkan.Efektif terlihat dari ketuntasan individual hasil belajar pengetahuan (keterampilan berpikir) siswa kelas IV sebesar 90,\%. Kendala yang dihadapi dalam penelitian ini adalah siswa belum terbiasa menggunakan keterampilan berpikir masalah sehingga perlu penambahan waktu tersendiri untuk melatihkan keterampilan tersebut. Berdasarkan hasil analisis data dapat disimpulkan bahwa perangkat pembelajaran IPA dengan menggunakan Scientific Approach yang dikembangkan layak dapat melatihkan keterampilan berpikir siswa yang digunakan dalam pembelajaran pada mata pelajaran IPA.
\end{abstract}

Kata Kunci : Pembelajaran IPA, Scientific Approach, Hasil Belajar, Keterampilan Berpikir

\section{PENDAHULUAN}

Orientasi pendidikan adalah terjadinya peningkatan dan keseimbangan antara kompetensi sikap (attitude), keterampilan (skill) dan pengetahuan (knowledge). Sesuai peraturan menteri pendidikan dan kebudayaan nomor 67 tahun 2013, kurikulum 2013 bertujuan untuk mempersiapkan manusia indonesia agar memiliki kemampuan hidup sebagai pribadi dan warga negara yang beriman, produktif, kreatif, inovatif, dan afektif serta mampu berkontribusi pada kehidupan bermasyarakat, berbangsa, bernegara, dan peradaban dunia. Berdasarkan orientasi tersebut, berarti proses pembelajaran diharapkan dapat mengkondisikan siswa sebagai manusia seutuhnya, memiliki pengetahuan, keterampilan, dan perilaku yang baik. Pembelajaran juga sebaiknya berpusat pada siswa (student centered) dan penilaian lebih mementingkan proses daripada hanya hasil akhir. 
Keterampilan berpikir siswa sangat penting untuk masa depannya. Beberapa ahli dalam bidang pembelajaran mengemukakan pendapat yang serupa, yakni sesuai dengan pendapat Gedgrave (2009) bahwa proses mendapatkan pengetahuan lebih penting daripada produk. Untuk suatu pembelajaran materi IPA tertentu, yang bertujuan untuk menumbuhkan keterampilan berpikir siswa di kelas, guru bisa menggunakan pendekatan yang dapat membuat siswa lebih aktif dan menggunakan keterampilan berpikir dari setiap aktifitas belajarnya di Kelas atau dengan kata lain, strategi pembelajaran yang digunakan tersebut mampu mengupayakan agar pembelajaran yang terpusat pada guru (teacher oriented) berubah menjadi terpusat kepada siswa (student oriented) atau siswa aktif belajar (SAL/Student Active Learning). Peran guru hanya berperan sebagai fasilitator.

Undang-Undang Nomor 20 Tahun 2003 tentang Sistem Pendidikan Nasional menyebutkan bahwa kurikulum adalah seperangkat rencana dan pengaturan mengenai tujuan, isi, dan bahan pelajaran serta cara yang digunakan sebagai pedoman penyelenggaraan kegiatan pembelajaran untuk mencapai tujuan pendidikan tertentu. Berdasarkan pengertian tersebut, ada dua dimensi kurikulum, yang pertama adalah rencana dan pengaturan mengenai tujuan, isi, dan bahan pelajaran, sedangkan yang kedua adalah cara yang digunakan untuk kegiatan pembelajaran.

Hal tersebut di atas merupakan harapan dalam dunia pendidikan pada umumnya dan khususnya pendidikan dasar, namun jika melihat pengajaran IPA di SD sekarang ini ternyata masih sangat memprihatinkan. Keprihatinan pembelajaran IPA di SD ini tampak pada penggunaan metode ceramah yang masih lazim dipergunakan. Selain itu guru memegang peranan sebagai sumber informasi utama. Sementara siswa hanya menjadi pendengar setia dan tidak dibiasakan untuk mencoba sendiri pengetahuan itu, sehingga perolehan pengetahuan siswa tidak bermakna dan cepat terlupakan.

Untuk itu guru hendaknya memandang pembelajaran ipa tidak hanya menekankan pada hasil, tetapi juga menekankan pada proses memahami konsep materi yang disampaikan. Jika guru dalam mengajarkan konsep IPA lebih menekankan pada proses yaitu siswa mengkontruksi pengetahuannya sendiri untuk memahami masalah atau objek yang diamati, maka dapat membawa dampak positif bagi kemajuan belajar siswa yang berorientasi pada peningkatan hasil dan prestasi siswa. Upaya yang dilakukan untuk meningkatkan mutu hasil belajar IPA dikembangkan terus menerus seperti penyerpunaan kurikulum, peningkatan kemampuan guru, pengembangan perangkat IPA di SD. Namun kenyataan dilapangan terlihat bahwa pemahaman konsep dan keterampilan berpikir secara umum masih belum sesuai dengan apa yang diharapkan.

Berdasarkan penjelasan di atas, dapat dikatakan bahwa tujuan pembelajaran IPA di Sekolah Dasar adalah membentuk dan mengembangkan kognitif, afektif, psikomotor, kreativitas serta melatih siswa berpikir kritis dalam mengaktualisasikan diri dan memahami fenomena-fenomena alam yang ada dilingkungannya, sehingga nantinya siswa dapat menghadapi tantangan hidup yang semakin kompetitif serta mampu menyesuaikan diri dengan perubahan-perubahan yang akan terjadi di lingkungan sekitarnya. Pembelajaran IPA harus dibuat lebih menarik dan mudah dipahami, karena IPA lebih membutuhkan pemahaman dari pada penghafalan saja.

Salah satu alternatif yang dapat membuat siswa lebih aktif dalam kegiatan pembelajaran serta memperhatikan suasana yang nyaman dan menyenangkan serta erat kaitannya dengan pengembangan keterampilan berpikir siswa sekolah dasar adalah dengan menggunakan pendekatan scientific approach. Pembelajaran scientific approach. Melalui scientific approach juga dapat membantu guru mengaitkan antara materi materi 
IPA dengan situasi dunia nyata peserta didik, dan mendorong peserta didik membuat hubungan antara pengetahuan yang dimilikinya dengan penerapannya dalam kehidupan mereka sehari-hari, baik sebagai anggota keluarga dan masyarakat, dengan konsep itu hasil pembelajaran diharapkan lebih menarik bagi peserta didik, dan dapat meningkatkan kemampuan berpikir siswa dengan baik.

Dengan dibuatnya pengembangan perangkat pembelajaran yang berorientasi Scientific approach yang diajarkan dapat menumbuhkan keterampilan berpikir yang lebih baik sehingga informasi yang diperoleh lewat pelajaran dapat menyebabkan perubahan nilai positif pada diri siswa.

Berdasarkan uraian di atas, peneliti akan mengembangkan perangkat pembelajaran berorientasi scientific approach (meliputi RPP, Buku Siswa, LKS, dan Lembar Penilaian) untuk melatihkan keterampilan berpikir siswa SD. dengan mengajukan judul "Penerapan Scientific Approach pada Pengembangan Perangkat Pembelajaran IPA Berorientasi Scientific Approach Untuk Melatihkan Keterampilan Berpikir Siswa".

\section{METODE}

Penelitian ini termasuk penelitian pengembangan (developmental research), karena mengembangkan perangkat pembelajaran IPA berorientasi scientific approach untuk melatihkan keterampilan berpikir siswa. Perangkat yang dikembangkan adalah Rencana Pelaksanaan Pembelajaran (RPP), Buku Siswa, Lembar Kerja Siswa (LKS), Lembar Penilaian (LP). Model pengembangan perangkat pada penelitian ini adalah four D Model dan menggunakan desain penelitian Pretest - Posttest Control Grup Design.

Selain perangkat yang dikembangkan, dilengkapi pula dengan instrumen penelitian berupa Instrumen Penilaian (Tujuan Pembelajaran, RPP, Buku Siswa, LKS, Keterbacaan Buku Siswa dan LKS ), Instrumen Validasi Lembar Penilaian, Instrumen Lembar Pengamatan (Keterlaksanaan RPP ,Aktivitas Siswa, Kendala Lapangan), Instrumen tes hasil belajar, dan Instrumen Angket Respon Siswa.

Instrumen yang digunakan dalam penelitian ini adalah instrumen penilaian perangkat, instrumen tes hasil belajar, instrument pengamatan, dan instrumen angket. Data yang dianalisis adalah validitas perangkat, keterbacaan LKS dan Buku Siswa, keterlaksanaan RPP, aktivitas siswa, ketuntasan hasil belajar, keterampilan berfikir kritis siswa, respon siswa dan kendala-kendala yang muncul dalam pembelajarab.

\section{HASIL DAN PEMBAHASAN}

Perangkat yang dikembangkan dalam penelitian ini adalah buku siswa, LKS, RPP, tes hasil belajar (pengetahuan, keterampilan dan sikap), serta tes keterampilan berpikir.

\section{A. Validitas Perangkat Pembelajaran}

Perangkat pembelajaran yang dikembangkan oleh peneliti meliputi Rencana Pelaksanaan Pembelajaran (RPP), Lembar Kerja Siswa (LKS), buku ajar siswa, instrumen penilaian hasil belajar siswa, dan instrumen penilaian keterampilan berpikir siswa. Perangkat ini mengikuti langkah scientific approach yang diawali dengan fase mengamati, fase menanya, fase mencoba, fase menalar dan fase mengkomunukasikan dimana siswa menyajikan hasil diskusi kelompoknya kepada kelompok lainnya sambil menerima sanggahan, tanggapan terhadap apa yang disampaikan yang diharapkan dapat menjadi pembelajaran bagi siswa yang meliputi aspek sikap religi, aspek sikap sosial, aspek pengetahuan dan aspek keterampilan sehingga siswa memiliki kompetensi yang baik . Perangkat pembelajaran divalidasi oleh validator sebelum diimplementasikan pada tahap 
uji coba terbatas. Diskusi tentang validitas perangkat pembelajaran yang telah dikembangkan adalah sebagai berikut:

\section{Rencana Pelaksanaan Pembelajaran (RPP)}

RPP merupakan panduan penting dalam pelaksanaan pembelajaran, oleh karena itu setiap pendidik pada satuan pendidikan berkewajiban menyusun RPP secara lengkap dan sistematis agar pembelajaran berlangsung secara interaktif, inspiratif, menyenangkan, menantang, efisien, memotivasi peserta didik untuk berpartisipasi aktif, serta memberikan ruang yang cukup bagi prakarsa, kreativitas, dan kemandirian sesuai dengan bakat, minat, dan perkembangan fisik serta psikologis peserta didik.

Untuk mewujudkan RPP dengan kriteria tersebut, penulis berusaha sungguhsungguh melalui konsultasi kepada pembimbing dan mempelajari berbagai literatur yang mendukung, termasuk contoh-contoh RPP dari beberapa peneliti sebelumnya. Dari hasil ramuan antara komponen-komponen yang harus ada dalam RPP, alur pembelajaran dengan scientific approach yang didalamnya terdapat indikator-indikator keterampilan berpikir dan hasil penilaian oleh validator 85\% komponen-komponen RPP sudah valid, dan $15 \%$ perlu perbaikan (RPP layak digunakan dengan revisi kecil). Pencapaian penilaian tersebut menunjukkan bahwa RPP yang dikembangkan terdapat langkah-langkah model scientific approach, yang dapat melatih keterampilan berpikir siswa sesuai dengan tujuan pengembangan perangkat.

\section{Buku Siswa}

Peneliti mengembangkan buku sebagai panduan dan sumber belajar bagi siswa dalam mempelajari materi perubahan sifat benda. Selama proses ujicoba, Buku Siswa dibagikan kepada siswa, kemudian siswa dibimbing untuk menemukan informasi penting yang diperlukan untuk memcahkan masalah dalam percobaan yang nantinya akan dilakukan oleh siswa.

Hasil penilaian keterbacaan Buku Siswa menunjukkan, bahwa siswa tertarik terhadap isi dan tampilan sebesar 90\%, ketertarikan terhadap penampilan buku siswa sebesar 95\%, pada kemudahan dalam memahami uraian atau penjelasan dari buku siswa masih terdapat 35\% siswa mengatakan ada sedikit, dan kemudahan dalam memahami gambar, grafik dan ilustrasi terdapat $90 \%$ siswa mengatakan memahami. Secara keseluruhan siswa tertarik dan mudah memahami buku siswa tersebut, dan diharapkan dapat memotivasi siswa untuk membaca, memahami, dan kemudian dapat meningkatkan pengetahuan serta kemampuan siswa untuk menghadapi ujian. Hal tersebut sesuai dengan pendapat Arends (2012) bahwa membangun komunitas belajar yang produktif dan memotivasi siswa untuk terlibat dalam kegiatan pembelajaran bermakna adalah tujuan utama pembelajaran. Hasil penilaian tersebut menunjukkan bahwa Buku Siswa yang dikembangkan layak dijadikan buku panduan bagi siswa maupun guru dalam mengelola pembelajaran untuk melatihkan keterampilan berpikir siswa.

\section{Lembar Kerja Siswa (LKS)}

LKS yang dikembangkan mengikuti pola pembelajaran scientific approach untuk keterampilan berpikir siswa berdasarkan tujuan pembelajaran yang didalamnya terdapat perumusan pertanyaan, merumuskan dugaan sementara, melakukan percobaan, menarik kesimpulan dan kemudian setiap kelompok presentasi hasil.. LKS yang dihasilkan dengan scientific approach tersebut telah divalidasi dan mendapatkan penilaian layak digunakan dengan revisi kecil $(3,80)$ untuk digunakan dalam pembelajaran.

Hasil penilaian siswa terhadap keterbacaan LKS menunjukkan, bahwa ketertarikan terhadap isi LKS sebesar 90\%, ketertarikan terhadap penampilan LKS sebesar 95\%, 
kemudahan dalam memahami uraian atau penjelasan dari LKS sebesar 65\% dan 35\% yang mengatakan ada sedikit, serta sebanyak 90\% kemudahan dalam memahami maksud pertanyaan LKS siswa. Secara keseluruhan siswa tertarik dan mudah memahami LKS tersebut dan diharapkan mampu menuntun siswa untuk berpartisipasi dalam pembelajaran, memotivasi belajar siswa dan mencapai ketuntasan dalam belajar. Hal tersebut sesuai dengan pendapat Widjajanti (2008) bahwa LKS berfungsi untuk membangkitkan minat siswa, menyelesaikan tugas perorangan dan kelompok, menjadikan siswa lebih aktif dalam proses belajar, dan meningkatkan kemampuan siswa dalam memecahkan masalah.

\section{B. Kepraktisan Perangkat Pembelajaran}

Kepraktisan perangkat pembelajaran yang dikembangkan didasarkan pada keterlaksanaan perangkat pembelajaran di kelas. Nilai kepraktisan perangkat pembelajaran diperoleh berdasarkan hasil uji coba di lapangan, dan dari uji coba tersebut diperoleh hasil pengamatan terhadap proses pembelajaran, angket respon siswa terhadap perangkat pembelajaran setelah mengikuti pembelajaran. Diskusi tentang kepraktisan perangkat pembelajaran yang telah dikembangkan adalah sebagai berikut:

\section{Keterlaksanaan Pembelajaran}

Pada RPP terdapat tiga kegiatan yaitu pendahuluan, kegiatan inti, dan kegiatan punutup dan secara keseluruhan dari semua tahap-tahap kegiatan yang ada di dalam RPP pada uji coba I terlaksana dan secara rata-rata keseluruhan skor keterlaksanaannya adalah $100 \%$ dengan nilai 3,81 (terlaksana dengan baik), hal ini menunjukkan bahwa rencana pembelajaran menggunakan scientific approach pada pertemuan I, II, dan III telah diimplementasikan dalam proses pembelajaran di kelas walaupun kegiatan pembelajaran yang telah dilakukan untuk melatih keterampilan berpikir yang menerapkan scientific approach yang terdiri dari fase mengamati, fase menanya, fase menalar, fase mencoba dan fase mengkomunikasikan masih ada siswa yang sedikit perlu bimbingan.

Pada kegiatan pendahuluan, guru memulai dengan menyampaikan apersepsi kepada siswa dan menyampaikan secara garis besar tujuan pembelajaran yang hendak dicapai. Masalah yang disajikan pada awal kegiatan adalah permasalahan yang terkait dengan kehidupan sehari-hari sehingga kegiatan pembelajaran yang dilakukan akan lebih bermakna. Siswa kemudian diarahkan guru untuk melakukan pengamatan, melihat, membaca dan mendengar terkait materi yang akan diajarkan agar siswa mampu merumuskan pertanyaan dengan jelas terkait hal-hal yang belum dimengerti. Pada fase berikutnya guru membimbing siswa untuk menyiapkan dalam kegiatan penyelidikan agar aktif berpartisipasi dalam pembelajaran.

Pada kegiatan fase melakukan percobaan, guru membimbing siswa untuk mendefinisikan istilah-istilah, membimbing siswa untuk merumuskan hipotesis berdasarkan pengetahuan yang dimiliki. Pada kegiatan ini, guru melaksanakan bimbingan yang lebih intensif karena siswa belum terbiasa dan untuk merumuskan hipotesis. Dari setiap kegiatan percobaan, siswa mengamati dan mencatat apa-apa yang didapatkan pada saat melakukan percobaan.

Pada pertemuan pertama siswa melakukan kegiatan penyelidikan/percoabaan mengenai cahaya dapat merambat lurus dan cahaya dapat menembus benda bening dengan difasilitasi bahan-bahan yang dapat mendukung siswa menemukan sendiri informasi yang terkait tujuan pembelajaran. Pada pertemuan pembelajaran kedua, siswa melakukan percobaan untuk membuktikan cahaya dapat dipantulkan, dan sama pada pertemuan pertama siswa difasilitasi alat dan bahan untuk melakukan percobaan sehingga 
siswa dapat menemukan sendiri informasi dari tujuan melakukan kegiatan pecobaan. Hampir sama pada pertemuan sebelumnya, pada pertemuan ketiga siswa melakukan kegitan penyelidikan/percoabaan mengenai cahaya dapat dibiaskan.. Hasil pengamatan siswa selama melakukan percobaan selanjutnya didiskusikan dalam kelompok . Kemudian guru membimbing siswa membuat kesimpulan dan menganalisis data yang telah dikumpulkan. Hasil diskusi kelompok selanjutnya dikomunikasikan lewat prsentasi secara klasikal dimana setiap kelompok secara bergilliran menyampaikan hasil diskusinya lalu mendapatkan tanggapan dari kelompok lainnya. siswa harus memperoleh pemahaman dalam proses mengomunikasikan hasil pengetahuan kepada siswa lain.

Pada kegiatan penutup, guru bersama-sama siswa menyimpulkan hasil pembelajaran yang telah dicapai pada pertemuan ini, kemudian sebelum menutup pembelajaran guru memberikan nasehat kepada siswa untuk lebih giat lagi belajar dan mengulang kembali pembelajaran yang didapatkan disekolah pada saat sampai di rumah.

Berdasarkan pembahasan di atas dapat diketahui bahwa perangkat Rencana Pelaksanaan Pembelajaran (RPP) yang dikembangkan oleh peneliti merupakan perangkat yang reliabel dan memiliki kategori baik sehingga layak untuk digunakan untuk melatihkan keterampilan berpikir siswa.

2. Aktivitas Siswa dalam Proses Pembelajaran

Pembelajaran IPA dengan menerapkan scientific approach menempatkan guru sebagai fasilitator dan siswa sebagai subyek pembelajaran, hal tersebut tergambar dari aktivitas siswa yang dominan dalam mengikuti proses pembelajaran, antara lain: Memperhatikan penjelasan guru atau teman, Membuat pertanyaan, bertanya pada guru atau teman, Membaca, Melakukan pengamatan percobaan, berkerjasama, Bertanggung jawab terhadap tugas kelompok dan Mengemukakan ide (menjawab pertanyaan).

Pada kelas eksperimen (kelas IVa) Secara umum menunjukkan bahwa pada setiap pertemuan siswa melaksanakan aktifitas yang diharapakan dalam pembelajaran. Rata-rata besar frekuensinya adalah pertemuan pertama $88 \%$, pertemuan kedua $90 \%$ dan pertemuan ketiga 90\%. Dalam pembelajaran siswa dihadapkan pada permasalahan autentik dan melakukan diskusi untuk membuat prosedur sendiri dalam mencari pemecahan masalah. Aktivitas siswa sesuai dengan tingkatan otonomi mengalami peningkatan dalam hal mendiskusikan tugas dan menyampaikan pendapat, sedangkan aktivitas siswa mengalami penurunan dalam membaca atau mencari informasi, mencatat, dan mendengarkan penjelasan guru. Aktifitas siswa yang berhubungan dengan proses pembelajaran secara lansyung meningkatkan kualitas belajar siswa menjadi deep learning (light,and cox,2009).

Berdasarkan hasil analisis aktivitas siswa di atas dapat disimpulkan bahwa pembelajaran pada pertemuan kedua dan ketiga terjadi peningkatan aktifiatas dan memiliki persentase yang tinggi sehingga Instrumen Pengamatan Aktivitas Siswa dapat dikatakan reliabel.

\section{Respon Siswa Setelah Pembelajaran}

Berdasarkan hasil analisis respon siswa terhadap pengembangan perangkat sebagian besar siswa memberikan respon positif terhadap ketertarikan, keterbaharuan dan kemudahan dalam memahami komponen pembelajaran. Respon tersebut menunjukkan bahwa siswa dapat menerima dengan baik semua komponen pembelajaran yang meliputi buku siswa, LKS, materi pembelajaran, suasana belajar dan cara guru mengajar. Menurut Arends (2008) jika masalah yang diberikan kepada siswa membuat mereka merasa tertantang, baru dan menarik maka dalam proses pembelajarannya siswa 
akan mengerahkan seluruh upaya untuk menyelesaikan masalah tersebut baik secara individual maupun kelompok dan dapat memicu motivasi interistik pada siswa

Respon ketertarikan siswa terhadap komponen pembelajaran yaitu materi pembelajaran (95\%), buku siswa (87\%), LKS (90\%), suasana belajar (95\%), dan cara guru mengajar (95\%). Respon siswa terhadap keterbaruan komponen pembelajaran yaitu materi pembelajaran (95\%), buku siswa (80\%), LKS (97,5\%), suasana belajar $(97,5 \%)$, dan cara guru mengajar (95\%). Respon siswa terhadap kemudahan memahami komponen pembelajaran yaitu bahasa dalam buku siswa (80\%), materi buku siswa $(77,5 \%)$, contoh soal $(80 \%)$, LKS $(87,5 \%)$, dan cara guru mengajar (92,5\%). Respon siswa terhadap ketertarikan siswa dalam proses pembelajaran dengan scientific approach (95\%). Respon siswa terhadap penjelasan guru dan bimbingan guru (97,5\%). Berdasarkan hasil data tersebut menunjukkan bahwa sebagian besar siswa memberikan respon positif. Hal tersebut berarti siswa merasa jelas dengan penjelasan guru pada saat pembelajaran dan siswa sangat berminat jika pembelajaran menggunakan scientific approach diajarkan untuk pokok bahasan selanjutnya.

\section{Keefektifan Perangkat Pembelajaran}

\section{Hasil Belajar Siswa}

Hasil belajar siswa yang dinilai dari penelitian ini mencakup tiga ranah, yaitu ranah pengetahuan (keterampilan berpikir), keterampilan dan sikap. Hal ini sesuai dengan kompetensi lulusan yang merupakan kualifikasi kemampuan lulusan yang mencakup sikap, pengetahuan, dan keterampilan peserta didik yang harus dicapainya dari suatu satuan pendidikan pada jenjang pendidikan dasar dan menengah (Depdikbud, 2013). Hasil belajar pengetahuan menitikberatkan pada indikator-indikator keterampilan berpikir yang telah dibuat. Hasil belajar keterampilan menitikberatkan pada penilaian kinerja siswa dalam merakit alat, menggunakan alat dan melaksanakan percobaan dalam proses pembelajaran, sedangkan hasil belajar sikap menitikberatkan pada penilaian social sosial (bersikap jujur, teliti dan disiplin, memberikan argument, berpendapat, bekerjasama dalam kelompok) dan spiritual (berdoa, memberi salam, mengucapkan syukur, dan konsisten dalam ucapan dan perbuatan,).

a. Hasil Belajar Kompetensi Pengetahuan.

Hasil belajar pengetahuan lebih cocok diperoleh dari metode tes, hal tersebut sesuai dengan pendapat Tatsuoka (2009) bahwa mengukur pengetahuan (kognitif) bukanlah tugas yang mudah karena tidak mungkin untuk mengamati mereka, oleh karena itu pengetahuan digolongkan latent variables. Hasil belajar pengetahuan pada uji coba lapangan di kelas eksperimen (kelas Va) terdapat 14,75 \% ( 6 siswa) tidak tuntas dan semua Indikator tuntas dengan persentasesebesar $86,25 \%$, pada kelas kontrol (Vb) terdapat 52 \% ( 24 siswa) dan 7 indikator tidak tuntas. Hail Paired Sample t-Test setelah pembelajaran pada kelas ekperimen (Va) yang diberi perlakuan dan kelas kontrol (Vb) diperolehl diperoleh nilai sig. $=0,000$ dengan Ho ditolak. Hasil ini menunjukkan Kedua rata-rata populasi adalah tidak sama (rata-rata pos test kelas eksperimen (Va) dan kelas kontrol (Vb) kontrol adalah tidak sama atau berbeda secara nyata), maka dapat disimpulkan bahwa peningkatan keterampilan dan kelas eksperimen (Va) berbeda secara signifikan dengan peningkatan kemampuan kelas eksperimen (Va) yang diberi perlakuan lebih tinggi daripada kelas kontrol (Vb). Selain itu hasil diatas menunjukkan bahwa proses pembelajaran dengan menggunakan scientific approach berhasil membuat siswa mencapai standar kompetensi yang diharapkan sesuai dengan pencapaian indikator yang diharapakan dalam proses pembelajaran, hal tersebut sesuai dengan pendapat Anderson \& 
Krattwohl (2001) bahwa proses kognitif yang paling banyak dijumpai dalam tujuan-tujuan di bidang pendidikan, yaitu mengingat, kemudian memahami dan mengaplikasikan, ke proses-proses kognitif yang jarang dijumpai, yakni menganalisis, mensintesis, dan mengevaluasi.

Tabel 2. uji paired sample t test pretest

\begin{tabular}{|l|l|c|}
\hline Kelas & Sig. & Keputusan \\
\hline Eksperimen & & \\
\hline Kontrol & & Ho diterima \\
\hline
\end{tabular}

\section{Kriteria :}

Ho Kedua rata-rata populasi adalah sama(rata-rata pre test kelas eksperimen (Va) dan kelas (Vb) kontrol adalah sama atau tidak berbeda secara nyata)

H1 Kedua rata-rata populasi adalah sama (rata-rata pre testeksperimen $\mathrm{n}$ kontrol adalah tidak sama atau berbeda secara nyata)

Tabel 2. uji paired sample t test postest

\begin{tabular}{|l|l|l|}
\hline Kelas & Sig. & Keputusan \\
\hline Eksperimen & & \\
\cline { 1 - 1 } & 0.000 & Ho ditolak \\
\hline
\end{tabular}

\section{Kriteria :}

Ho Kedua rata-rata populasi adalah sama (rata-rata pos test kelas eksperimen (Va) dan kelas (Vb) kontrol adalah sama atau tidak berbeda secara nyata)

$\mathrm{H} 1$ Kedua rata-rata populasi adalah tidak sama (rata rata pos test kelas eksperimen (Va) dan kelas kontrol ( $\mathrm{Vb}$ ) kontrol adalah tidak sama atau berbeda secara nyata)

Data pada kelas eksperimen (kelas Va) saat pelaksanaa pretest hasilnya seluruh siswa mendapatkan nilai yang rendah, namun setelah memberikan perlakuan kemudian diadakan postest terlihat nilai siswa jauh lebih baik dari nilai yang didapat pada waktu melakukan pretest dan secara klasikal tuntas. Bebeda dengan kelas kontrol secara klasikal dinyatakan tidak tuntas. Pembelajaran menggunakan scientific approach dapat melatihkan keterampilan berpikir yang terbukti dari hasil belajar meningkat.

b. Hasil Belajar Kompetensi Sikap

Hasil belajar sikap pada kelas eksperimen (kelas Va) dan kelas kontrol (kelas Vb) yang diamati dalam proses pembelajaran terdiri dari dua, yaitu sikap spiritual dan sosial (Depdikbud, 2013). Sikap piritual meliputi: berdoa; mengucapkan salam; mengucapkan syukur; konsisten antara lisan dan perbuatan. Sikap sosial meliputi: bersikap jujur, teliti dan disiplin; memberikan argument; bertanya, berpendapat dan menjawab pertanyaan; dan bekerja sama. Berdasarkan hasil analisis data yang dilakukan pengamat selama proses pembelajaran dari dua orang pengamat diketahui bahwa siswa memiliki kecendrungan mengalami peningkatan sikap spiritual yang baik Hasil belajar sikap spiritual dan sosial pada uji coba lapangan dinyatakan tuntas karna memiliki rata-rata lebih dari $75 \%$. 
Ketuntasan tersebut dapat terwujud karena indikator-indikator sikap dilatihkan dalam pembelajaran, sebagai contoh adalah mengucapkan syukur ketika berhasil mengerjakan aktifitas tertentu, sikap ini memang benar-benar dibiasakan dalam pembelajaran.

Berdasarkan hasil analisis data pada kelas eksperimen diperoleh persentase ketuntasan $90 \%$ untuk masing-masing pada percobaan tiap pertemuan tersebut seluruh siswa mencapai ketuntasan yang berarti aspek-aspek yang dinilai terlaksana dengan baik sedangkan pada kelas kontrol tidak dapat menilai keterampilan dikarnakan tidak melaksanakan percobaan.

\section{Temuan Hasil Penelitian}

Beberapa temuan dalam penelitian ini didasarkan pada hasil analisis data dan diperkuat dari hasil implementasi perangkat pembelajaran. Temuan-temuan dalam penelitian ini dapat diuraikan sebagai berikut:

1. Penilaian validator terhadap RPP sebesar $85 \%$ sudah valid dan ada perlu sedikit perbaikan dan layak digunakan dengan revisi kecil, LKS sebesar 3,80 dengan kategori layak digunakan dengan revisi kecil, buku siswa sebesar 3,50 dengan kategori layak digunakan dengan revisi kecil, instrumen penilaian hasil belajar pengetahuan, keterampilan, sikap, dan keterampilan layak digunakan dengan revisi kecil.

2. Kepraktisan perangkat pembelajaran yang telah dikembangkan pada uji coba dapat dilihat dari:

a. Keterlaksanaan tahapan pembelajaran pada semua pertemuan sebesar $100 \%$, dengan rata-rata skor keterlaksanaan pertemuan I, II, dan III sebesar 3,60 dengan kategori terlaksana dengan baik.

b. Aktivitas siswa dalam pembelajaran sangat mendukung penerapan scientific approach, diantaranya memperhatikan penjelasan guru atau teman, Membuat pertanyaan, bertanya pada guru atau teman, Membaca, Melakukan pengamatan percobaan, berkerjasama, Bertanggung jawab terhadap tugas kelompok dan Mengemukakan ide (menjawab pertanyaan). Secara umum menunjukkan bahwa pada setiap pertemuan siswa melaksanakan aktifitas yang diharapakan dalam pembelajaran. Rata-rata besar frekuensinya adalah pertemuan pertama $88 \%$, pertemuan kedua $90 \%$ dan pertemuan ketiga $90 \%$.

c. Respon ketertarikan siswa terhadap komponen pembelajaran menunjukkan bahwa sebagian besar siswa memberikan respon positif.

3. Keefektifan perangkat pembelajaran yang telah dikembangkan pada uji coba dapat dilihat dari:

a. Ketuntasan individual hasil belajar di kelas eksperimen (terdapat 14,75 \% ( 6 siswa) tidak tuntas dan semua Indikator tuntas dengan persentase sebesar 86,25\%, pada kelas kontrol (Vb) terdapat 52 \% ( 24 siswa) dan 7 indikator tidak tuntas. Hail Paired Sample t-Test setelah pembelajaran pada kelas ekperimen (Va) yang diberi perlakuan dan kelas kontrol ( $\mathrm{Vb}$ ) diperolehl diperoleh nilai sig. $=0,000$ dengan Ho ditolak. Hasil ini menunjukkan Kedua rata-rata populasi adalah tidak sama (rata-rata pos test kelas eksperimen (Va) dan kelas kontrol (Vb) kontrol adalah tidak sama atau berbeda secara nyata), maka dapat disimpulkan bahwa peningkatan keterampilan dan . kelas eksperimen (Va) berbeda secara signifikan dengan peningkatan kemampuan kelas eksperimen (Va) yang diberi perlakuan lebih tinggi daripada kelas kontrol (Vb).

b. Semua siswa pada kelas eksperimen mengalami peningkatan keterampilan berpikir.

4. Kendala-kendala yang ditemukan dalam menerapkan pembelajaran adalah: a) siswa belum terbiasa menggunakan keterampilan berpikir masalah sehingga perlu 
penambahan waktu tersendiri untuk melatihkan keterampilan tersebut. b) beberapa siswa masih menggunakan bahasa daerah selama proses pembelajaran sehingga pelu membiasakan mereka menggunakan bahasa indonesia, dan c) penggunaan sarana dan prasarana yang belum maksimal, seperti lokasi sekolah yang berada didekat pasar sehingga perlu memaksimalkan tenaga kerja disekolah yaitu satpam untuk menkondusifkan lingkungan sekolah.

\section{SIMPULAN}

Berdasarkan temuan tersebut, penelitian dapat disimpulkan bahwa Penerapan Scientific Approach pada pengembangan perangkat pembelajaran IPA untuk melatihkan keterampilan berpikir siswa dinyatakan valid, praktis dan efektif untuk digunakan dalam pembelajaran.

\section{DAFTAR PUSTAKA}

Abdullah, Mikrajuddin. (2004). Sains Fisika 2 Untuk SMP Kelas VII. Jakarta: Erlangga

Anderson and Krathwohl. (2001). A taxonomy for learning, teaching and assessing: Revision of bloom's taxonomy of educational objectives, Bridged Ed. New York: Longman.

Arends, Richard I. 2008. Learning to Teach. Yogyakarta: Pustaka Belajar.

Arends, R. I. (2012). Learning to teach. New York: McGraw-Hill.

Arikunto, S. (2013). Prosedur Penelitian Suatu Pendekatan Praktek. Jakarta: Rineka Cipta.

Butterworth, J. And Thwaites, G. 2013.Thinking Skills: Critical Thinking and Problem Solving. Cambridge University Press. Cambridge

BSNP. (2014, Mei 28). Instrumen penilaian buku teks pelajaran tahun 2014. Dipetik Juni 26, 2014, dari Kelompok Peminatan MIPA: http://bsnp-indonesia.org/id/?p=1340

Carin, Arthur A., and Sun, Robert B. 1989. Teaching Science Throught Discovery. Colombus Merill Publishing Company.

Dahar, R.W.2006. Teori-Teori Belajar dan Pembelajaran. Jakarta:Erlangga.

Dahar, R.W.1996.Teori-Teori Belajar. Jakarta: Erlangga.

Hamdayani, A.S. 2009. Taksonomi Bloom Dan Solo Untuk Menentukan Kualitas Respon Siswa Terhadap Masalah Matematika. Tersedia (http://www.learningandteaching.information/learning/solo.htm).

Halliday \& Resnik. 1997. Fisika Jilid 2 edisi ketiga. Jakarta. Penerbit Erlangga.

Howe,A, C. And Jones, L. 1993. Engaging Children in Science. N. Y: Merill

Ibrahim, M. (2014). Inovasi pendidikan162 sains dalam implementasi kurikulum 2013. Inovasi Pendidikan Sains dalam Menyongsong Pelakasanaan Kurikulum 2013, Vol. 3, No.1, 1- 
12.

Ibrahim, M. 2002. Pelatihan terintegrasi berbasis kompetensi: pengembangan perangkat pembelajaran. Surabaya: Direktorat Sekolah Lanjutan Tingkat Pertama Departemen Pendidikan Nasional.

Ibrahim, M. 2005. Seri Pembelajaran Inovatif Asesmen Berkelanjutan Konsep Dasar, Tahap Pengembangan dan Contohnya. Surabaya: Unesa University Press.

Ibrahim, M. Tanpa Tahun. 2007. Contoh Tes Penilaian Kemampuan Berpikir (Solo Taksonomi). Surabaya: Kumpulan Tulisan.

Institude of Museum Ana Library Service. 2009. Museums, Libraries Ana 21 Century Skill. Washington: IMLS Office of Strategic Parnership.

Khotimah, Khusnul. 2013. Pengembangan Perangkat Pembelajaran Berdasarkan Model Inquiri Terbimbing dalam Rangka Melatihkan Keterampilan Proses Siswa. Magister Pendidikan . Universitas Negeri Surabaya.

Light, G. And Cox, R.2009. Learning and teaching in Higher Education, The Reflective Profesional (second Edition). London.

Martin, D. J. 2009. Elementary Science Methods A Constructivist Approach. Wadsworth Cengage Learning. USA

Marzano Robert J, dkk. 1988. Dimensions of Thinking: A Framework for Curriculum and Unstruction. Virginia: ASCD.

McClure, John R, Brian sonak, and Hoi K. Suen. (1999). “ Concept map assesment of classroom learning learning: reliability, validity, and logistical practically". Journal of research in science taching. Vol. 36, No.4, pp. 475-492

Ngadiman. 2014. Pengembangan Perangkat Pembelajaran Fisika Menggunakan Pendekatan saintifik Untuk meningkatkan Hasil Belajar dan Melatihkan Keterampilan Berpikir Kritis Siswa. Tesis. Magister Pendidikan. Universitas Negeri Surabaya

Nagl, M. G., Obadovic, D.Z.,\& Segedinac (2012). Efectifitive teaching of physics and scientific method. TEM Journal, 2, Vol.1, 85-89.

Nieeven, Nieke. 1999. Prototy to reach product quualty. In Jan Vanden Akker, R.M. Brach, Gutafson, N. Nieveen \& Tj Ploom (eds), Design Approaches and tools in Education and Training. Dorgrecht, Netherland Kluwer Academic Publisers.

Mulyasa, H. E. (2013). Pengembangan dan implementasi kurikulum 2013. Bandung: Remaja Rosdakarya.

Mccollum, 2009. A Scientific Approach to Teaching. (http;//kamcollum.wordpress.com).

Permendikbud. 2013. Peraturan Menteri Pendidikan dan Kebudayaan Republik Indonesia Nomor 65 tahun 2013 Tentang Standar Proses Pendidikan dasar dan Menengah ". 
Jakarta: Departemen Menteri Pendidikan dan kebudayaan republik indonesia.

Permendikbud. 2013. Peraturan Menteri Pendidikan dan Kebudayaan Republik Indonesia Nomor 67 tahun 2013 Tentang Standar kurikulum sekolah dasar. Jakarta:

Departemen Menteri Pendidikan dan kebudayaan republik Indonesia

Puspitasari Ria. 2012. Pengertian Keterampilan Berfikir. AMKIM08.

Prasetyowati, Eka Novvy. 2013. Model Pembelajaran Inquiri Pada Pokok Bahasan Larutan Penyangga Untuk Meningkatkan Penguasaan Konsep Dan Keterampilan Berpikir Kritis Siswa SMA.

Ratumanan, G.T. T. Laurens. 2006. Evaluasi Hasil Belajar Yang Relevan Dengan Memecahkan Problematika Belajar dan Mengajar. Bandung: CV. Alfabeta

Rizki, Miftakhur. 2013. Pengembangan perangkat pembelajaran IPA Kelas IV Berorientasikan Model Pemaknaan Untuk Melatihkan Keterampilan Berpikir Pada Siswa Sekolah Dasar. Tesis. Magister Pendidikan. Universitas Negeri Surabaya.

Rudolph, J.L. 2005. Epistemology for the masses: The origins of the scientific method Ni American schools. History of Education Quarterly, 45, 341-376

Sagala, S.2003.Metode Belajar Mengajar.Bandung: Alfabeta

Schulz, B. (2008). The Impotance Of Soft Skill Education Beyond Academic Knowledge. Journal Of Language and Comunication

Sidharta Arief. 2005. Keterampilan Berfikir. Bandung: PPPTK IPA.

Simister, C.J. 2007. How to Teach Thinking and Learning Skills. London. Paul Chapman Publishing.

Simon, K.D and Klein, J.D. 2007. The Impact Of Scafofolding and Student Achiefment Levels in A Problem-Based Learning Environment Instrucsional Science, 35:41-72

Slamet Prawiharono. 1993. Sains Biologi. Jakarta: Bumi Aksara.

Slavin, E. R. (2011). Educational psychology. theory and practice. USA: Pearson

Suhadi. 2003. Pengembangan Perangkat Untuk Mengajarkan Keterampilan Berpikir Melalui Pokok Bahasan Organisasi Kehidupan di SLTP. Magister Pendidikan. Universitas Negeri Surabaya.

Sutrisno Joko. 2008. Menggunakan Keterampilan Berpikir untuk Meningkatkan Mutu Pembelajaran. Jakarta

Purnama, R. Dicky Agus \& Pribadi, BennyA. (2014)" Penilaian performa dalam pembelajaran sains". Jurnal pendidikan. Volume 15, Nomor 1, Maret 2014, halaman 22-30 
Thiagarajan, S., Semmel, D. S., \& Semmel, M. I. 1974. Instructional Development for Training teachers of exceptional Children: A sourcebook.Bloomington:Indiana University.

Tselfes, Vasilis \& Paroussi, Antigoni. (2009). Science and Theatre Education: A Crossdisiplinary Approach of Scientific Ideas Addressed to Student Teachers of Early Chilhood Education. Springer Science education vol.18

Tuckman, B.W. 1978. Conucting Educational Research. San Diego. Harcourt Brace Jovanivich. Publisher

Wieman, C. (2007). Why not try a scientific approach and scientific inquiry: Tensions in teaching and learning. USA: Wiley InterScience

Varelas, M and Ford M. 2009. The scientific method and scientific inquiry: Tensions in teaching and learning. USA: Wiley InterScience

Verawati, Erie. 2013. Pengembangan Perangkat Pembelajarn Berbasis Model Learning Cycle 5E Untuk Meningkatakan Penguasaan Konsep Dan Keterampilan Berpikir Kritis Siswa SMK Pada Materi Pokok Laju Reaksi. Tesis. Magister Pendidikan.

Universitas Negeri Surabaya.Ilmiah Dan Hasil Belajar Siswa Kelas I SLTP 6 Singaraja.

Jurnal Pendidikan dan Pengajaran IKIP Negeri Singaraja. ISSN.0215-8250

Rusli, M. A. 2012. Pembelajaran Fisika Melalui Pemrosesan Top Down berbasis Scaffolding Untuk Melatihkan Keterampilan Berfikir Kritis. Unesa: Jurnal Penelitian Pendidikan Sains.

Sagala, S. 2011. Konsep dan Makna Pembelajaran. Bandung: Penerbit Alfabeta. Schafersaman, S. D. 1991. Introduction to Critical Sears, F. W. dan Zemansky, M. W. 1962

Fisika Untuk Universitas 1. Jakarta: Trimitra Mandiri.

Setyorini, U., Sukiswo, S.E.,\& Subali, B. 2011. Penerapan Model Problem Based Learning Untuk Meningkatkan Kemampuan Berpikir Kritis Siswa SMP. Jurnal Pendidikan Fisika Indonesia.

Slavin, R. E. 2011. Psikologi Pendidikan Teori dan Praktik. Edisi 9. Jakarta: PT. Indeks.

Solso, R. L., Maclin, O. H., \& Maclin, M. K. 2008. Psikologi Kognitif. Nevada: pearson Education.

Sugiyono, 2013. Metode Penelitian Pendidikan (Pendekatan Kuantitatif, Kualitatif dan R\&D).

Bandung. Alfabeta. Thiagarajan, S.,Semmel, D.S., \& Semmel, M.I. 1974. Instructional Development for Training Teachers of Exceptional Children, Indiana: Indiana University. 